This is the accepted manuscript of the article, which has been published in

Journal of Social History. 2009, 43(2), 285-305. https://doi.org/10.1353/jsh.0.0273

\title{
War of Hearts
}

Love and Collective Attachment as Integrating Factors in Finland During World War II

Authors:

Ville Kivimäki, Åbo Akademi University, Finland (corresponding author)

Address: Yliopistonkatu 39 C 25, 33500 Tampere, Finland

E-mail: ville.kivimaki@abo.fi

Tuomas Tepora, University of Helsinki, Finland

Address: Department of History, PO Box 59, 00014 University of Helsinki, Finland

E-mail: tuomas.tepora@helsinki.fi

\section{Abstract:}

The article examines personal and collective bonds of attachment in war. The Finnish experience in World War II is used to bring together various theoretical viewpoints stretching from nationalism research to gender studies and from the history of emotions to psychoanalytically-oriented approaches. The aim is to understand the central and often perverted role of love both in the endurance and motivation for wartime violence. Three interwoven aspects are studied: emotional bonds between soldiers, male-female relations in war, and collective, national bonds of attachment as a source of sacrifice and motivation. Contradictions and fragilities of emotional commitment in war and some of its post-war consequences in Finland are also discussed.

Neither the primary group theory nor the nationalist ideology as such can explain the soldier's willingness to fight. Many soldiers killed and were killed voluntarily for the sake of what they considered most meaningful and dear in their lives. These bonds of attachment formed the social fabric of the society at war. Positive emotions in war are inseparable from the destructive ones. Love could promote violence and hatred, and occasionally other attachments had to give way to an all-demanding patriotism.

Keywords: World War II, Finland, military history (modern), comradeship, bonds of attachment, emotions, gender, nationalism. 


\section{War of Hearts}

\section{Love and Collective Attachment as Integrating Factors in Finland During}

World War II ${ }^{\mathrm{i}}$

The so-called new military history has replaced the purely "military" and heroic histories of war with histories of mutilation, trauma, chaos, genocide, and repression. ${ }^{\mathrm{ii}}$ Unquestionably, a set of draconic repressive techniques was necessary to make people endure suffering, and to persuade them to fight and commit brutal acts. Still the glorification of war in propaganda and literature, for instance, should not only be seen as manipulation, by which common people were forced to make sacrifices for the cause of the elite. ${ }^{\text {iii }}$ Romantic, even elevated accounts of war could echo true sentiments and the desire for consolation among the wartime population. ${ }^{\text {iv }}$ Often they served the purpose of concealing and making up a reality of war too horrible to be confronted as such; yet at the same time they could be based on real experiences of genuine meaningfulness. Disturbingly, for many the war truly seemed to be a fulfillment of "positive" desires, such as the need to love and to be loved, and to experience one’s own life as meaningful. Love - more than hate - made people fight ${ }^{\mathrm{v}}$.

In the following piece, we examine primarily the "positive" emotions in war - personal and collective bonds of attachment, altruism, the experience of fulfillment - rather than "negative" emotions - fear, hatred, and aggression. Our aim is by no means to dispute war's devastating and violent nature, but to understand the central and often perverted role of love in both enduring and motivating this violence. As British military psychologists discovered during World War II, the so-called hate training aimed at making killers out of male citizens proved to be inefficient and even harmful, whereas the positive motivations of protecting one's family and country turned out to be much more sustaining. ${ }^{\mathrm{vi}}$ 
The main interest of military sociology regarding attachment relations has been in the cohesion of the so-called soldiers' primary group. ${ }^{\text {vii }}$ An emphasis on the primary group as an analytical category was introduced to counter theories of combat motivation, which had stressed military discipline, internalized patriotism, and national re/degeneration. ${ }^{\text {viii }}$ Many studies on the primary group have aimed at producing applicable knowledge for future military conflicts, and the research problem has been approached from the practical perspective of creating “fighting power” through different organizational and educational techniques and arrangements. If, however, one is interested in the wider social and cultural aspects of war, the primary group theory is inadequate. More far-reaching and complex attachment relations than mere buddy-ties were in play, and they had a deep impact on both soldiers' behavior and on the society at large during and after the war.

World War II meant three different wars for Finland: the Winter War against the Soviet invasion from November 1939 to March 1940; the Continuation War of 1941-44 as an officially unallied "brothers-in-arms” offensive with Nazi Germany against the Soviet Union; the Lapland War between September 1944 and April 1945, the aim of which was to drive out the German troops in Northern Finland. ${ }^{\text {ix }}$ To analyze the meaning of the bonds of attachment in war, we will study three interwoven aspects of this Finnish war experience: emotional bonds between soldiers, male-female relations in war, and finally, collective, national bonds of attachment as a source of sacrifice and motivation. First, our emphasis will be on frontline soldiers, but in the last two chapters we will pay more attention to the home front. We will conclude with a discussion on the contradictions and fragilities of emotional commitment in war and some of its post-war consequences. The article is intended primarily as a methodological opening in understanding attachment relations in war. We take Finnish 
history in World War II as a case in point to illustrate and bring together various theoretical viewpoints varying from nationalism research to gender studies and from the emerging history of emotions to psychoanalytically-oriented approaches. The empirical evidence is drawn from previous Finnish research literature and from the primary sources of our own studies. The latter include extensive reminiscence collections on war in the Folklore Archives of the Finnish Literature Society (SKS KRA) ${ }^{\mathrm{x}}$, wartime letters, novels, newspapers, public speeches, and patient files in military psychiatric hospitals.

"Real and honest love": Comradeship between the soldiers

As Knut Pipping has demonstrated in his classic sociological study of a Finnish frontline company, close "buddy-ties” were important for combat motivation also in Finland. The basic unit of identification was the company, which was further divided into smaller groups of different functions. The smallest of them - and already based mostly on the soldiers' selforganization - was the so-called “cooking team” (keittoporukka) of two to four soldiers. Some considered this merely a practical arrangement, but for many it developed into a deep relationship of mutual care-taking, brotherly sharing, and, finally, altruistic sacrifice. ${ }^{\text {xi }}$ Soldiers in their small units took over "familial" roles: sergeant-majors and captains were the mothers and fathers of the company, while soldiers were brothers among each other. When creating attachment relations, military organizations tended to adopt the family ideal as a model of emotional ties. Many experienced this "family of brothers" as emotionally the most satisfying bond of their lives, and as one veteran wrote 30 years after the war: "It feels both tragic and comic that I have never experienced real and honest love anywhere else than in the dugouts." xii 
What was different from familial ties, though, was the central role of violence at the root of this line-up: the soldiers’ primary group was a unit of killing and dying together, and the mutual bonds of attachment were to serve this function. Care-taking and even tenderness were always coupled with the presence of violence against both the enemy and the outsiders on one’s own side. Unlike family ties, the soldiers’ primary group was constituted by shared dangers and shared violence. The experience of killing seems to have been a taboo that united those who broke it - something that could not be shared with civilians and rear-area "toy soldiers," and which thus strengthened the community of "the baptized in violence."xiii Unlike the killing, the shared experience of mortal danger was easier to transcribe into collective symbols and discourses; Finnish frontline soldiers formed a community of sacrifice and suffering. The Christian basis of this martyrs' communion - especially in contrast to "atheist Bolsheviks" - is very visible in accounts of frontline Christmas celebrations:

"At that moment in the dugout we felt that we had been redeemed. All the fallen heroes of the past, both the brave ones and the cowards, had returned, and with them even the one who had been executed for his madness. They all sat on the bunks in the semi-dark dugout. That Christmas I think each of us felt as though the hand of the beloved gently caressed his cheek and touched the back of his hand. Angels seemed to dance around the red-hot fireplace. There on our wooden bunks, some of us fell asleep to Christmas. Others left to take up their dark sentry duties, tightly clutching their cold rifles. We all realized that the light of Christmas would never fade from the hearts of the Finnish people." xiv 
Another soldier tells how he heard Finnish men singing Christmas hymns at night at the front and how this powerful sound rolled over to the Soviet side: "The second song is: - 'A Mighty Fortress Is Our God' ... Instinctively one pulls oneself together, the posture straightens, as though a strong current had passed through one's body and ended up in the brain. One feels clear, free and peaceful.” ${ }^{\mathrm{xv}}$ Christmas connected the men to the symbolic structure of the "Finnish nation," and the simultaneous celebration of the Holy Night across the country created the "imagined community" described by Benedict Anderson. ${ }^{\text {xvi }}$

As these examples demonstrate, the bonds of attachment among soldiers cannot be reduced to merely concrete, inter-personal "buddy-ties.” This emotional bond has a broader and more imaginary level of comradeship. As Thomas Kühne has demonstrated, primary group theory cannot explain the astonishing ability of the German Wehrmacht to avoid disintegration even in the last months of World War II. Although the German military tried to uphold the continuity and local character of its divisional and regimental personnel, mounting losses and constant redeployments inside the division constantly dissolved the primary groups. It was the internalized ideal of militant comradeship that enabled soldiers over and over again to reestablish new buddy-ties within a short period of time and not to be devastated by the loss of their previous Kameraden. The ideology of comradeship finally enveloped the whole manly nation in a collective of comrades, Volksgemeinschaft. ${ }^{\text {xvii }}$

A "horizontal community" of citizens formed the basis of nationalist ideology, also in preWorld War II democracies. ${ }^{\text {xviii }}$ Young boys and girls were taught at an early age to form strong intra-generational bonds through various children's and youth organizations, which often had a paramilitary character. “The Cult of Youth” may have had its heyday in Germany and in other totalitarian regimes, in which traditional family ties were more clearly 
subordinated to the horizontal community of "brothers" and "sisters." Nevertheless, in bourgeois democracies, too, children were keenly integrated into a network of different youth organizations. In Finland, Seija-Leena Nevala-Nurmi has aptly called the constellation of voluntary civil defense organizations "a defense family,” in which one’s growth from childhood to adolescence, and from adolescence to adulthood was accompanied by a new horizontal community of "brothers and sisters."xix In schools and finally in the military service almost the whole age cohort of Finnish men was instructed in the ideals of comradeship, sacrifice, and self-control. ${ }^{\mathrm{xx}}$ In this mental climate the comradeship of soldiers symbolized the nation more vividly than any other human relation. Such a brotherhood-inarms can be described as a default setting for manly attachment relations in the pre-war Finnish society, and later in war.

The imaginary level of comradeship helps to understand the peculiar ecstasy one may find in descriptions of, for instance, suicidal counter-attacks, which surely did not serve the survival of the primary group. In his popular documentary novel of the Winter War, front officer Erkki Palolampi gives an exalted description of this sacrificial comradeship in battle:

"In this realm of death, only one encouraging emotion rises, one truth lives on: the brotherhood-in-arms, the community of suffering. .... At times, one may see several men die a horrible death at once, but, in the name of brotherhood-in-arms, one must not dwell on the fallen, must not spend one moment remembering them. One must not be seized by pain and sorrow - for the name of the fallen brother, the sacrifice of a soldier who has done his duty, obliges one to continue the work of the departed at the same bloody site of sacrifice." ${ }^{\mathrm{xxi}}$ 
From the army's point of view, too personal and especially libidinal relations between the soldiers were dangerous in this respect. A Finnish military psychiatrist tells of a soldier who had fallen in love with his comrade; when his beloved one died at the front, the soldier was too shocked and depressed to go on fighting. ${ }^{\text {xii }}$ Personal attachment to one’s comrade could be a strong cement gluing the primary group together, but it could also make soldiers vulnerable to paralyzing grief and a loss of meaning in the event of a comrade's death. In order to avoid such personal dependencies, manly love had to be projected on the abstract of collective comradeship, and not on personal friends or lovers. ${ }^{\text {xxiii }}$

Thus, in risking their lives to save a wounded comrade, and even more in lethal attacks, soldiers were not only concerned with the physical survival of a fellow soldier. They were actualizing the ideal of comradeship, and preserving “something greater” than one's own life, or the life of one's comrade. In chaotic and hopeless circumstances, "the front” was upheld by this abstract, yet intensely lived-through attachment to the ideal of brotherhood-in-arms, xxiv which was crystallized by loss and violence. As Thomas Kühne has pointed out, comradeship was both a safe haven in the midst of overwhelming horrors and at the same time the very motor for the continuing suffering and violence. Ultimately and momentarily, the whole constellation could turn upside down: the unity among comrades was no longer the prerequisite for combat motivation; the combat itself - the sacrifice and the violence became the requirement for social life among soldiers. ${ }^{\mathrm{xxv}}$

But did the soldiers only fight for their brothers-in-arms, or to fulfill the ideal of comradeship? A previous comparative study on Finnish soldiers' combat motivation in summer 1944 has implied that the importance of comradely ties was highest among the youngest conscripts and tended to decrease among older reservists. ${ }^{\text {xxvi }}$ Young boys, often 
insecure about their masculine identity, were more destined to seek mutual homosocial acceptance among other soldiers. Consequently, older married soldiers were more motivated by the desire of protecting their families and homes.

“A mother, a wife, a bride, or simply a woman”: Male-female relations in war

According to Freud's perception of mass psychology, a couple relationship excludes group attachment. Individual desires and relationships are a structural threat to the group cohesion and therefore should be harnessed for the benefit of the group and the nation. ${ }^{\text {xxvii }}$ Even if the soldiers at the front rarely saw any women for months, an imaginary eye of a woman was constantly following their actions: women were the constitutive Other in shaping soldiers’ manly identity ${ }^{\text {xxviii }}$, and news from home could decisively boost and depress their spirits. Soldiers’ attachment relations to women were primarily dependent on a soldier's age and marital status and could either reinforce or weaken their combat motivation. The youngest conscripts might be only 18-years-old. For them, the relation to mother was still very important and they often had no wives, girlfriends, or sexual experience whatsoever. The oldest reservists could be around 40, and naturally in a very different position.

As in comradeship, the relation to women had a concrete, personal level and a general, imaginary dimension. Both aspects became visible, for instance, in correspondence between soldiers and women on the home front, which was of crucial importance for the motivation of the whole army. ${ }^{\text {xix }}$ Soldiers were also keen to find anonymous female pen pals besides their relatives, girlfriends, and wives. Such a correspondence could develop into a close relationship, or it served the function of manifesting gendered identity politics of war on an 
abstract level - soldiers tended to read the letters of their female pen pals aloud to their comrades, and thus these women became the "common property" of the whole male group. ${ }^{\mathrm{xxx}}$

For young conscripts "full manliness" was still something to be achieved and proved, and women were something to be “conquered” to demonstrate one's manly status to other fellowsoldiers. A group of soldiers could use real and imaginary women to strengthen homosocial group cohesion by sharing their sexual adventures and by talking about women in general:xxxi

“One really young cadet officer .... boasted that he had got laid the same night as the battle of Tyrjä started and we were already in assault positions: - and we were lying there on a footpath and the captain rode over us - Now that doesn't sound like anything, but at that time the story had splendor. It had some of the same spirit as 'Song of the Athenians. ${ }^{\text {xxxii }}$ A soldier ready to attack for his fatherland gets laid at the last minute. Silently we listened to his proud bragging, all the more inspired to continue the story of men and war."xxxiii

In the gendered imagery of war, overtly sexualized “common women” were accompanied by angel-like idealizations. Utmost sacrifices demanded a pure cause for themselves, and women became the bearers of this purity. In the midst of the filthiness on the front, everything good and worthy in life was deposited with morally elevated, faithful women back home, who thus upheld the meaningfulness of soldiers' lives and rose above their personal qualities to become emotionally recharged symbols of purity. Mothers, sisterly nurses, and virginal young women often personified such ethereal female objects, protected by soldier-men. ${ }^{\text {xxxiv }}$ A quotation from a soldier's letter on Mother’s Day, 14 May 1944: 
"Sixth vision: a boy on guard at the frontlines. Foe in front of him, behind him his dear home. There in the silence of the night, staying awake on her bed and praying for her son - Mother. .... Ninth vision: a thankful son. I am thankful for Mother's love, care, and efforts, for the wakeful nights, guidance, and prayers. I thank Mother for everything. I thank the graceful Lord - for Mother.”xxxv

The outlook of young soldiers vacillated between a desire to return to their mother's protection, and an insecure sexual desire for the rather abstract and unattainable woman. By entering the military service and experiencing war, young men often left their childhood homes and maternal care for the first time, stepping from boyhood to real manhood. ${ }^{\mathrm{xx} x \mathrm{i}}$ This rite de passage was closely accompanied by educational measures and instructions, most of them delivered through boys' adventure literature. This genre portrayed under-aged boys not only in their war effort at home, but also identifying themselves with their serving fathers and other soldiers at the front. In line with the underlying traditions of the genre, female characters are usually absent. In a number of books, though, mothers attain an unexpectedly central presence. The boys’ war experience, as projected here, functions not only as a symbol of separation from home and maternal protection in the name of the father(land), but seeks to establish a new relationship between mother and son - a relationship that balances both independence and care. While the overarching demands of the fatherland provide the juvenile reader with a sense of compulsory sacrifice, it is the memory of the family, identified with the mother, that keeps this imperative ambivalently voluntary and neatly complements the first patriotic - dimension of sacrifice. At times, personal familial attachment makes the explicit official perpetuation of sacrifice as a manly and bellicose virtue even redundant. ${ }^{\text {xxxvii }}$ 
If the soldier was yet to sacrifice his life, it had to have a proper meaning. As Ilona Kemppainen has analyzed, the ideal death in wartime Finland was that of a heroic young soldier giving his life for the sake of his mother and the fatherland. It was a pure, disinterested sacrifice without any "disturbing” connotations of small orphans and widows in need of (financial) support. This was indeed the ideal; as the war dragged on and soldiers grew wearier, the older, married reservists found it especially difficult to accept and identify with such an abstract mother-son constellation - it could even prove to be counter-productive in its unrealistic idealism. ${ }^{\text {xxxvii }}$ Even so, women were the last consolation in the agony of death, giving reassurance of the attachment relation that had offered meaning to the soldier's life and death. A medical officer gives an account of a soldier's last moments in a field hospital:

“The wounded tells about his home, relatives, asks to send greetings. It is difficult for the nurse, tears are not far. She promises to do everything that the patient asks. His consciousness darkens, but the grip of his hand stays firm. With that grip, the patient holds on to this life. The nurse is a mother, a wife, a bride, or simply a woman. He feels no pain, his thankful glance tries to reach the nurse. Consciousness dims. The patient will soon depart this world." $x x x i x$

Women's role was to send the men (or boys) to war, and then welcome them back again, dead or alive. Finnish Evacuation Centers for the Fallen were largely occupied by female employees, whose duty was to wash and prepare the bodies before they were sent back to their families. ${ }^{\mathrm{xl}}$ In this dramatic setting, men were the actors of war, but women gave meaning to it; it was their role to encourage and support, to be admiring spectators, and to build up the scenery for heroism and sacrifice. ${ }^{\text {xli } ~ " M a r t t a ", ~ a g e ~} 17$ in the winter of 1943-44, remembers how the girls and younger pupils at school organized a farewell party for the one-year-older 
boys who were about to enter the army and go to war. The party was a cheerful event, where the boys stepping into soldierly manhood were decorated with bottle caps as medals of honor. Many of these youngsters returned in wooden coffins the following summer. Martta's account of the death of her close friend, with whom she had planned her future, captures both the deep personal grief and the gendered mindscape of sacrifice:

“-- So you departed, lyceum boys. -- Elias, you were not from that school, you were from further away. You left too, and returned with flowers in your hands. Some lotta ${ }^{\text {lii }}$ at the front must have put them there." xliii

The importance of women in motivating continued fighting was not limited to young men. Older, married reservists also considered the role of a soldier-protector to be embedded in their concept of manliness and being a husband. Often these male-female relations were more personal than among young conscripts. Married soldiers had other concrete commitments and bonds of attachment at home to think about, and they were more prone to evaluate pragmatically the necessity of sacrifices at the front against the possible gains and risks. In late fall 1941, as the Finnish Army was advancing further east, casualties were mounting, and the army had become an occupier instead of a defender of the homeland. Many reservists started to contemplate the meaningfulness of their sacrifices. Objections to the march forward were spreading, and finally a whole infantry regiment went on full strike. Strikers’ wives sent letters to encourage their men, and the soldiers of the regiment - mainly from the workingclass districts of Helsinki - used comradely solidarity similar to pre-war industrial actions to reach their aims. ${ }^{\text {xliv }}$ The example demonstrates how both family ties and strong comradeship could occasionally turn against the military. 
As a hypothesis for further study, similar dynamics may be observed in the statistics of desertion and psychiatric casualties. In the offensive of 1941, the average deserters and soldiers suffering mental collapse were considerably older than in the defensive battles of 1944 against the Soviet onslaught. This might indicate that defensive fighting was considered more meaningful than offensive among older, married soldiers. ${ }^{\text {xlv }}$ But in spite of the lower average age in 1944 compared with 1941 - and in support of Freud's thesis at the beginning of this chapter - the proportion of young conscripts among deserters and psychiatric cases never seems to have reached the proportions of the same age cohort among soldiers in frontline combat units. Young, unmarried men proved to be more sustainable and ready for self-sacrifice both in offensive and defensive warfare than their older, married comrades.

The idealization of women as worthy of sacrifice could result in a backlash of misogyny. This became apparent, for instance, in sexual violence against Soviet female soldiers. Finnish soldiers' relation to women was polarized and highly tense; it seemed to oscillate between extreme positions of utmost worship and brutal sexualization - probably more so among younger, unmarried soldiers. ${ }^{\text {xlvi }}$ But older soldiers, too, were constantly concerned over the faithfulness of their wives back at home. This concern had partly a national dimension, as one of the most common rumors was about the attraction of Finnish women to German soldiers who were deployed in Northern Finland. ${ }^{\text {xlvii }}$ Men at the front considered themselves as protectors of their women - women were thought to even demand this from their men - and thus the object of this sacrifice had to be kept pure; otherwise the meaning of suffering would have been endangered. As the violence at the front grew grimmer, it could start to overflow its conventional boundaries and turn against the "demanding” women at home. ${ }^{\text {xlviii }}$ In the postwar crime boom, the number of rapes climbed significantly over the pre-war levels. ${ }^{\text {xlix }}$ 
War and collective attachment

The previous chapters have shown how nationalism in war was intertwined with other attachment relations and how this synthesis strengthened - and occasionally threatened collective integration. Nevertheless, love for one's fatherland could also be a direct attachment relation, and have a dynamics of its own.

Judging from the Finnish wartime mainstream media and national celebrations, World War II marked an unparalleled burst of love for one’s fatherland, not just a brief "spirit of the Winter War.” As a reflection of the European trend in ideas, the nation was often addressed as a living organism existentially dependent on its individual parts. In the wartime media, the idea of the nation, condensed in the trinity of "home, religion and fatherland," had to be internalized by every citizen. Wartime rhetoric and propaganda were, of course, used instrumentally to mobilize the masses, but they should not be considered solely from that perspective. Instead, propaganda should be seen in the context of the world view of both its producers and its recipients, or the society as a whole. The content of the propaganda is therefore inseparable from the cosmology of the (hegemonic) culture. ${ }^{l}$ Wartime rhetoric and gestures offer solace in the face of some fundamental concerns of the war-waging populations; these include fear, grief, and uncertainty about the future. The idealized and powerful in-group portrayed in propaganda is often a comforting and nearly omnipotent object to which the individual adheres in times of crisis. Propaganda and wartime rhetoric therefore produce reality, and can actually translate into experienced reality in the minds of war-affected individuals. 
Although it should be stressed that collective bonds of attachment and feelings of oneness as echoes of the "war trance" are brief at best, the phenomenon is documented throughout societies at war. ${ }^{\text {li }}$ In fact, the nation can be seen as almost concretely materializing itself in the minds of individuals, thus reinforcing the collective layers of identity, as in Germany during World War II. ${ }^{\text {lii }}$ The fate of the self was bound to the fate of the collective. This is especially manifest in an editorial in a conservative newspaper at the onset of the Winter War:

"The trivial I disappears as we comes instead. Every single drop of blood shed on the soil is our blood, every child's tear is our child's tear and even the smallest of deeds is meaningful to our family, the Finnish nation." "liii

The loss of individual boundaries, the self, to the large in-group, "the nation," during times of crisis is to be regarded as a coping strategy: the imagined strength of the nation's anonymous members is injected into the minds of its individuals. This can be an elevating experience. Sacrificing oneself for the benefit of the collective removes moral responsibility from individual shoulders. However, in Finland at the same time the individual's responsibility for him- or herself and his or her family also increased. Concentration on everyday duties and one's own survival, as well as fear and uncertainty about the future, suspended the contemplation of moral and cosmological questions. These issues were largely decided collectively.

The maintenance of enthusiasm for war relies on the justification of the common cause, which in turn requires a plausible external threat - real and imagined. During disturbing times, the environment is easier to split into clear-cut counterparts representing universal invariables of good and evil. ${ }^{\text {liv }}$ In Finland during the Continuation War, the content of the conservative 
newspaper propaganda illustrates genuine concern for the fate of the nation, one's own reference group and the writer's own position within these. In this manner, the emotionally charged metaphors of "mudslides," "surges of the East” or "the beast” fought off by God's elect people in a Christian newspaper perhaps mediated a deeper message of fear of the destruction of the moral universe than its purely propagandist value would indicate. ${ }^{\text {lv }}$

On a collective level, war can paradoxically create a collective sense of purpose, albeit only a momentary one. Uncertainty, although sometimes promoting chaos, can stimulate organized co-operation. There is nothing mythical in this process: the strength of societal bonds becomes crucial in helping people to cope in unexpected everyday situations. Notwithstanding the destructive and brutalizing consequences of war for everyday life, the everyday routine and mutual aid could create a sense of continuity in the midst of dire and sometimes nerve-shattering circumstances. For instance, despite serious material shortages many Finns felt obliged to contribute to the aid of the Karelian population in occupied Eastern Karelia during the Continuation War. ${ }^{\text {lvi }}$ In line with the Italian precedent from the 1930s, 100,000 persons exchanged their gold wedding rings for iron ones for the benefit of the war effort. $^{\text {lvii }}$

There is often something more to the collective sense of meaning in war than simply mutual aid. Indeed, in the beginning, war can transform everyday life briefly into an existentially elevated form of being by merging the individual into the collective will. ${ }^{\text {lviii }}$ Experienced and constructed - external threats unify the collective by strengthening the socio-cultural ties among the members of society - often across social boundaries. Fellow citizens become concretely felt allies sharing the same symbols, myths, habits, manners and even clothing. Sometimes minor cultural differences between warring nations or groups become major 
thresholds in the minds of the people. Unpleasant aspects of oneself are controlled and destroyed in the enemy image. ${ }^{\text {lix }}$ War breaks its own illusion quickly: war connects people, but it also separates them, eventually leaving people to cope by themselves. Just as the initial willingness to sacrifice unifies the collective, the all-pervading violence of war sooner or later erodes the sense of commonality.

The realm of the collectively experienced sense of meaning is inevitably that of the home front. The fatherland rarely manifests itself as the primary object of attachment in the trenches. Interestingly, the Finnish flag became an important mediating symbol between different social groups on the home front. After the Winter War in 1940, socialist insurgents who were killed in the Civil War in $1918^{\mathrm{lx}}$, or who perished in its aftermath, were commemorated on the state level under the national flag for the first time. At about the same time the social-democratic press heralded the nobility of this supposedly unifying national symbol. This signified more than merely trying to integrate the working population into the war effort, although the elites intended this as well; and it was more than an attempt by the lower strata of society to elevate its social status. These gestures on both sides indeed reflected an entire reorganization of the symbolic universe. Collective emotions of attachment and devotion were mirrored in the national flag, a symbol of common sacrifice. Workers' flags, which had been banned in the 1930s, were rehabilitated during the period between the Winter War and the Continuation War. They were not considered as threats to the structure of the nation any longer. ${ }^{\text {lxi }}$ The concept of the nation was renewed on an abstract level, as a proclamation in a social-democratic midsummer festival in 1940 demonstrates:

"After the last winter the state's flag has won its rightful place in our minds. For us it stands as the symbol of the independent and free state. Many a socialist and class- 
conscious worker fallen for the fatherland has been buried in the home-church yard draped in that flag."

At the front, on the other hand, collective symbols such as the flag were not important. The soldiers clung to more personalized amulets like letters from loved ones and Bibles carried in the breast pocket. Many soldiers believed that these tokens would protect them. ${ }^{\text {xiii }}$ The attachment to home and religion outweighed attachment to the fatherland, although the elevated rhetoric of patriotism was sometimes an integral part of reminiscences; the nation was re-established in the minds of the narrators, as can be seen in a soldier's diary entry in memory of a fallen comrade around the New Year 1939-40:

"Fatal bullets fly along the border, and often they reach a warm heart, from which the fluid of life flows out onto Finland's white snow. A young soldier sacrifices there his life for the fatherland and for those who have been so dear to him. He clenches his hand against his chest, for there in a pocket he has a picture of a young blond-haired girl. That girl is the dearest of all to him.... But now he carries the picture with him as a mascot, a blissful amulet."xiv

The devotion given to various amulets connected the Finnish and Soviet soldiers. Red Army soldiers, too, found solace in personal items: officially banned religion emerged in the form of personal crosses. Photographs of loved ones or a verse of poetry protected their bearers. ${ }^{\mathrm{lxv}}$

Following Émile Durkheim’s remarks, nationalism has been described as an immanent system of thought whose primary deity of worship is the nation itself. ${ }^{\text {lxvi }}$ In wartime, this mechanism is radicalized, with a certain kind of uncommunicative narcissism added to the collective 
attachment experienced. The nation is bound to attach every sentiment and emotion to itself. It disciplines private needs and desires in order to salvage the purity of the collective. A graphic illustration of this is the state-issued prohibition on dances in wartime Finland. Dancing, public or private, was considered defamatory to the sacrifices of the war, and the sensuality manifested in dancing seemed to undermine the collective efforts. The youth did not, however, conform to the prohibition, but organized clandestine dances out of the penetrating sight of the officials. During the Finnish war period the norms of society tightened and the agency of individuals was narrowed. Dissenting voices were muted. The diffusion of individual boundaries into collective ones reduces not just the moral responsibility of individuals but also their ability to do an individual reality check. ${ }^{\text {lxvii }}$ Revealingly, the two central hero types of wartime Finland were modest (young) dutiful soldiers and sacrificing mothers. ${ }^{\text {lxviii }}$

War reorganizes collective sentiments. The large group operates by projecting hatred and animosity outwards to on the enemy, thereby paving the way for horizontally felt bonds of attachment between society's own members, which is inherent to the idea of a nation. ${ }^{\text {lxix }}$ Interestingly, in the Finnish society the experience of World War II indeed led to a reshaping of the relationships between previous internal adversaries, at least on a symbolic level. War was a liminal experience: the future was and remained uncertain, both for individuals and for the collective. People from all walks of life lived through this transitory experience. The experience generated the myth of social unanimity during the Winter War. As described above, such oneness was a real, albeit brief phenomenon, but there is a mythical aspect to it, which in fact makes it all the more powerful. The Winter War represented the unmaking of the Civil War. The sudden solidarity it created came to represent the ultimate ideal of the community, and although only experienced briefly, it became a prerequisite for being a 
sovereign and real nation. ${ }^{\text {lxx }}$ In contrast to that, the Continuation War saw the state's grip on its citizens tighten. The public had to be persuaded to back up the occupation of Eastern Karelia. Towards the end of the war, war weariness became commonplace and the Winter War, along with its defensive nature, was already looked back on with nostalgia.

Post-war: Dance-mania, military cemeteries, and the trauma of broken attachments

Eventually the "war trance” described in the previous chapter leads to a conflict between objects of attachment: between the fatherland and the family, as well as between the idealized love of one's nation and the sheer lust for life. In fact, these elements were constantly present in wartime Finland. Perhaps in its most naked form, "the love" inspired by the war found its expression in the moral decadence and sexual promiscuity inherent to war's liminal circumstances. The uncertainty of the future and the proximity of death created a strong attachment to life itself, a sort of objectless desire, which easily transformed into violence. Wolfgang Schivelbusch has observed an outburst of bodily hedonism in “cultures of defeat.” A nation at war has demanded immense restraint of personal needs and desires, and as this wartime control collapses, the post-war period is marked by a wave of sensual vitality, eroticism, and dance-mania. ${ }^{\text {xxi }}$ Thus, for instance in Japan, post-World War II escapism culminated in the artistic endorsement of the eroticized and carnal body, which signified an antithesis to the self-sacrificial ideals of the body-politic. ${ }^{\text {lxxii }}$

In Finland, too, many tried to push aside their painful wartime pasts and to make the most of whatever was left of their youth. In the novel Juurettomat (The Rootless Ones, 1946), author 
and war veteran Unto Ahokivi described the bacchanalian experiences of his veteran protagonist in post-war Helsinki:

“A whirl of parties, hectic, hurrying to escape one’s thoughts with women, women .... who suffered from the same disease of depression and fervor as he did, escaping and seeking. They had all been lusty and feverish for experience, at the same time heedless and coldly sensible, maniacs who didn't think of the next day .... During that first peacetime winter, he had felt that the people were suffused with greedy and feverish desire to win back the lost years.”|xxiii

What was different in Finland, though, in comparison with the other defeated countries, was the political continuity from pre-war and wartime to the post-war society. Despite the feverish zest for life and the loosening of sexual morals during and after the war, there was no real political upheaval of wartime values, and the control of the state authority over its citizens was never released completely. It is indicative that the above-mentioned dance prohibition was not fully reversed until 1948. To a large extent, as Marja Tuominen has analyzed, the post-war backlash of emancipation and celebration of bodily hedonism in Finland had to wait until the youth radicalism of the 1960s and '70s, when the children of the war generation distanced themselves from the "dead” self-denial of their parents and challenged generational hegemony. ${ }^{\text {lxxiv }}$

The ideal sacrifice has to be voluntary and productive. Defeated societies in particular have to struggle to give meaning to lost causes. In Finland, too, many war veterans were disillusioned, and the newly rallied Left additionally discredited the wartime patriotic pathos. Nevertheless, the core value of the sacrifices for the collective memory was not seriously questioned until 
the 1960s. Perhaps more strikingly, the Finnish war effort resulted in the first redefinition of the value of the sacrifices of the defeated Reds in the Civil War. Those sacrifices, which had previously been regarded as nationally meaningless, began to be integrated into the official narrative of the nation-state. ${ }^{\operatorname{lxx}}$

The willingness to sacrifice for the nation has been explained psychologically by likening the nation to the primary group: during times of crises the elites are able to elicit from the people a collective devotion resembling the altruism felt towards kin members. The force of nationalism lies in its ability to equate the family and the nation. ${ }^{\text {lxxvi }}$ The space for an individual to decide the benefits of sacrificing oneself for the nation is limited. It is perhaps fruitful to consider the significance of war sacrifice as a constantly changing position between two extremes; as an offering for the familial collective or as a victim of the destructing collective. The conflict between the family and the nation became clearly visible in the conventions of the Finnish military funeral (“Hero’s Funeral”), where the display of individual grief was subordinate to collective grief. The fallen heroes were portrayed as having given their lives for the whole nation, often equating Christian symbolism and war sacrifice. The elevated rhetoric gave consolation and meaning to the bereaved, but at the same time the bereaved felt it important to be able to emphasize their personal emotions and the personal characters of their loved ones in obituaries as well as at funerals, if possible. ${ }^{\text {lxxvii }}$ Thus the fallen soldier was ambiguously positioned between the family and the nation.

After World War I, many of the remains of the fallen soldiers in European theatres of war were recovered, sometimes privately and secretly, from the European military cemeteries, thus exposing the conflict concerning the ownership of the fallen. ${ }^{\text {lxxviii }}$ Reclaiming the bodies of loved ones is a vital part of the process of mourning, and national celebrations for "the 
fallen heroes” were not enough to reconcile personal grief. ${ }^{\text {lxxix }}$ During World War II the Finnish military's exceptional convention to evacuate all the fallen to be buried in their home parishes interestingly combined national interests and familial ties. There existed - and still does - a military cemetery in every locality. ${ }^{\mathrm{lxx}}$ In this regard the Finnish society can truly be seen as acting like a "primary group” nestled in itself.

\section{Concluding remarks}

Why do emotions matter? Couldn’t the same historical phenomena be sufficiently explained with social psychological factors, such as group pressure, adaptation, and obedience, or with the analysis of wartime discourses as power relations and status concerns? We think that to study emotions in their wide-ranging historical contexts helps to understand how various social and cultural practices create mentalities, experiences, interaction, and behavior. Emotions shape, intensify, and transmit cultural meanings. Their analysis shifts the focus to individuals in their attempt to give meaning even to the most devastating historical experiences. Human identities and communities are based on emotional ties of love, attachment, trust, and desire, and, suffice to say, their opposites, with the objects and patterns of such emotions varying historically and situationally. Any history of emotions therefore addresses the dynamics, functions, and consequences of this tangled web of interpersonal and -communal relations. In the process, the complexity of human experience is recreated.

We have argued that neither the primary group theory nor the nationalist ideology as such can explain the soldier's willingness to fight. Both of them had an important role, but the soldiers did not simply act as marionettes of group psychological constants or as if "tricked by the 
elite” through nationalist indoctrination. Without any doubt, many soldiers stayed at the front because of a plain lack of options. Still, the coercive powers of the army and the state alone cannot explain why so many Finnish soldiers - the vast majority - decided to continue fighting when desertion and surrender were real options, and even when their primary group of fellow soldiers was dispersed. Coercion had its limits, too, especially in a democracy at war. In the end, the "soldier's sacrifice" had to be voluntary - otherwise, the nation or the state demanding this sacrifice would not have been worth it.

Soldiers killed and were killed voluntarily for the sake of what was considered the most meaningful in their lives. More often than not, the most meaningful was also the dearest. These bonds of attachment formed the social fabric of the society; maternal love, brotherly bonding, romantic and libidinal ties between men and women, the desire to attach one's self to a larger, protecting collective. At its best, the nation-state, unified by civic religion, could foster sincere altruism and empathic concern over one’s fellow citizens. It could offer personal life histories a context that was experienced as deeply meaningful and emotionally satisfying. Concrete attachment relations to fellow soldiers, family, and home were not the only things that mattered; something "greater than one’s own life" was created in the idealization of women, comradeship, and the fatherland. The good and "worthy of dying for" was deposited in these symbolic objects of attachment.

It seems evident that the most “effective” soldiers were young men in their early 20's; men who often had neither well-established couple relationships nor occupational identity. They were keen to demonstrate their manliness - as defined by contemporary culture - to themselves, to their comrades, and to the often merely imaginary women. In this context, especially small units appear to have fostered the emergence of extremely solid male bonds. 
Mothers - and their role in their sons' everyday lives - were still highly important to these men in their "liminal age". It is thus relevant that the Finnish wartime culture was so concerned over mothers’ willingness to sacrifice their sons for the fatherland. Older reservists were prone to similar attachments and sentiments, but their devotion to soldiering and selfsacrifice was often compromised by a conflicting bond to and a sense of responsibility for their wives and families.

A renewed historiographical focus on class and social status is likely to reveal remarkable variations in the emotional dynamics of war. Even though "the spirit of the Winter War" of 1939-40 seems to have fostered an albeit brief experience of classless unity, social hierarchies swiftly recovered to determine identities and attitudes. Patriotism as a collective attachment, for instance, was a real phenomenon among the Finnish wartime population, but its degree and substance varied in different social strata. Conservative and bourgeois segments of the population were more attached to the national romantic, apolitical ideal of the fatherland, applied to a mythologized Greater Finland, whereas the working class and the majority of small farmers adhered to an ideal of the nation more closely linked to the promise of social reforms. Both ideals certainly reinforced combat motivation and an overall will to resist the Soviet invasion, but they could also surface as conflicting attitudes and behavior. The abovementioned case of working class soldiers striking in the face of the supposedly "meaningless" sacrifices in fall 1941 is just one of a host of similar examples.

The emotional dynamics of war are always case-specific and have to be studied and compared as such. Historical characteristics of the Finnish case in World War II included the strong Christian conviction of experiencing the frontline comradeship as a community of brethren, which was elevated in suffering. The glorified role of motherhood in a soldier's sacrifice may 
have been more essential in Finland than in many other war-waging nations. The wartime enthusiasm for "uniting under the same banner" is only understandable through the history of the Finnish Civil War. The wars of 1939-45 gave the chance to reconcile the traumatic bloodletting of 1918. Furthermore, the military and political outcome of the war in 1944-45 avoiding an unconditional surrender to Soviet Union and the continuity of the sovereign state apparatus - shaped the Finnish politics of emotion: the attachment relations that had given meaning to the war sustained much of their patriotic value and were carried on into the postwar era.

Finally, Finland in World War II has to be considered as a case of a rather typical early $20^{\text {th }}$ century European nation-state with a large conscript army. The present war in Iraq could serve as a point of comparison to the Finnish case in 1939-45, where many of the decisive attachment relations of soldiers and civilians appear to be similar: comradeship, loyalties towards family and community, and patriotism are central in generating the motivation to fight on and certainly found in both conflicts. In many aspects, though, the cultural meaning, form, and mutual balance of these motivations can be expected to differ between the more traditional type of war and today’s "postmodern” and strongly "asymmetric” conflicts. To name but one example: As opposed to earlier conscript armies, the gradual dissolution of direct emotional links between the relatively small professional army and civil society seems to have emerged as one of the most significant features of the military cultures of the United States and the United Kingdom in the early $21^{\text {st }}$ century. Such a "marginalized," even effectively outsourced army is capable of waging wars in far-away countries without any substantial connection to the homeland. Against this backdrop, the home population is rarely aware or concerned with the intricacies of a particular conflict, let alone personally acquainted with individual soldiers. This important change in attachment relations has inevitable 
consequences for the politics of war and the military, for soldier's war experiences and their identities, and for their role as citizens and relations to their respective families.

Positive emotions in war are inseparable from destructive ones. These two not only co-exist, they nourish each other. Patriotism, together with the real or imagined threat to one's loved ones, easily led to projecting all the negative emotions and features onto the enemy. The nation-state at war tended to appropriate other attachment relations for its own purpose. Love could promote violence and hatred, and the other bonds of attachment, including the love for one’s own life, had to give way to all-demanding patriotism. In the context of modern nationalism, pro patria mori -type idealistic and altruistic sacrifice is in danger of being transformed into a self-purposeful celebration of death, of which National Socialism is a prime example. At a military cemetery in Pälkäne, a small commune in Southern Finland, the following text is inscribed for the fallen:

\author{
"For the Fatherland \\ 1939-1940, 1941-1944 \\ They loved not their lives \\ not even enough to shun death"
}

Such a delegation of attachment - lived through in violence, loss, and suffering - is painful to be called into question, and it tends to transfer to the following generations. It can be seen as an attempt to cement a lasting, collective meaning to those personal attachment relations, which the war had torn apart. Often the experiences of violence and loss were too painful, 
though, to be appeased so harmoniously. To a large degree, the trauma of war is the very incongruity of shocking personal experiences and the social order shared through language and aimed at consigning meaning to the given experiences. In such a crisis, the collective system of meaning may repress and even extinguish dissident voices of personal trauma, which are experienced as threatening to the stability of the social order. ${ }^{\text {lxxxi }}$ As we speak of war as a "meaningless slaughter" or as a "selfless sacrifice,” we are trapped in a plexus of long-lasting emotional commitments that still define many present-day identities. ${ }^{\text {lxxxii }}$ 
References:

${ }^{\text {i }}$ An earlier version of the article has been published in Swedish: Ville Kivimäki \& Tuomas Tepora, “För krig och kärlek: Kollektiv anknytning och kärlek som (des)integrerande faktorer i Finland under andra världskriget,” Historisk tidskrift 128 (2008): 3, pp. 427-450. We would like to thank Dr. Michael Jonas for his constructive comments on the manuscript.

ii For an overview on “new military history” see Joanna Bourke, “New Military History,” in Matthew Hughes \& William J. Philpott, eds., Palgrave Advances in Modern Military History (Basingstoke, 2006).

iii Juha Siltala, “Sodan psykohistoriaa,” in Tiina Kinnunen \& Ville Kivimäki, eds., Ihminen sodassa: Suomalaisten kokemuksia talvi- ja jatkosodasta (Helsinki, 2006), p. 45.

${ }^{\text {iv }}$ Cf. Jay Winter, Sites of Memory, Sites of Mourning: The Great War in European Cultural History (Cambridge, 1995), pp. 221-222.

v Joanna Bourke, An Intimate History of Killing: Face-to-Face Killing in Twentieth-Century Warfare (London, 1999), pp. 141-148, 168-170.

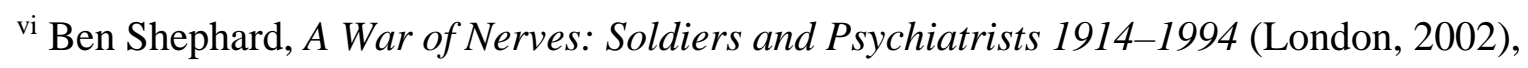
232-233; Bourke, An Intimate History of Killing, pp. 152-155.

${ }^{\text {vii }}$ For two pioneer works on the primary group, see S.L.A. Marshall, Men Against Fire: The Problem of Battle Command in Future War (New York, 1947); Edward Shils \& Morris Janowitz, “Cohesion and Disintegration in the Wehrmacht in World War II,” Public Opinion Quarterly 12 (1948): 2, pp. 280-315.

viii Simon Wessely, "Twentieth-century Theories on Combat Motivation and Breakdown,” Journal of Contemporary History 41 (2006): 2, pp. 273-278.

ix During the Continuation War, Finland occupied large areas of Soviet Eastern Karelia. Whereas the Winter War and the Continuation War were full-scale conflicts, the Lapland War 
against Germany was mostly fought with reduced conscript units after the army was demobilized in November 1944.

x Most notably the Korsuperinne (“The Trench Tradition”) Collection of 1973 (Korsu 1973), which consists of ca. 12,000 pages of war reminiscences mainly from the frontline soldiers.

${ }^{x i}$ Knut Pipping, Kompaniet som samhälle - Iakttagelser i ett finskt frontförband 1941-1944, Acta Academiae Aboensis, Ser. A, Humaniora, vol. XVI, no. 1 (Åbo, 1947), pp. 13-16, 128, 169-170.

xii SKS KRA, Korsu 1973, vol. IV, E.K., p. 2.

xiii Ville Kivimäki, “Sotilaan työ, siviilin taakka: ‘Vihollisen tuhoamisen’ dynamiikasta, kokemuksesta ja muistosta,” in Tiina Kinnunen \& Ville Kivimäki, eds., Ihminen sodassa: Suomalaisten kokemuksia talvi- ja jatkosodasta (Helsinki, 2006), pp. 191-208.

xiv SKS KRA, Korsu 1973, vol. II, A.H., p. 28.

xv SKS KRA, Korsu 1973, vol. IX, M.S., p. 21.

${ }^{x v i}$ Benedict Anderson, Imagined Communities: Reflections on the Origin and Spread of Nationalism, Rev. ed. (London, 1991).

xvii Thomas Kühne, Kameradschaft: Die Soldaten des nationalsozialistischen Krieges und das 20. Jahrhundert (Göttingen, 2006), pp. 167, 200—205.

xviii Anderson, Imagined Communities, pp. 7, 141-145.

xix Seija-Leena Nevala-Nurmi, “Girls and Boys in the Finnish Voluntary Defence Movement,” Ennen \& nyt (2006): 3-4, <http://www.ennenjanyt.net/2006_3/nevala.html>, retrieved 12 August 2008.

${ }^{x x}$ Anders Ahlbäck, Den beväpnade manligheten: Kön och nationalism i det mellankrigstida Finlands värnpliktsarmé, 1919-1939 (Åbo 2006), pp. 12-17, 168-174.

xxi Erkki Palolampi, Kollaa kestää (Porvoo, 1940), p. 242.

xxii Lauri Saarnio, “Sotaneurooseista,” Duodecim 56 (1940), p. 239. 
xxiii Cf. George L. Mosse, Nationalism and Sexuality: Respectability and Abnormal Sexuality in Modern Europe (New York, 1985), pp. 80-88.

${ }^{\text {xxiv }}$ E.g. in the final stages of the Winter War in February and March 1940, cf. Lasse Laaksonen, Todellisuus ja harhat: Kannaksen taistelut ja suomalaisten joukkojen tila talvisodan lopussa 1940 (Helsinki, 1999), pp. 330-337, 343.

xxv Kühne, Kameradschaft, pp. 147-149, 157-165, 169-171, 198.

xxvi U.E. Moisala \& Pertti Alanen, Kun hyökkääjän tie suljettiin: Neuvostoliiton suurhyökkäys kesällä 1944 Karjalan kannaksella veteraanitutkimuksen ja neuvostolähteiden valossa, Sotatieteen laitoksen julkaisuja no. XXVI (Helsinki, 1988), pp. 249-251. xxvii Sigmund Freud, Massenpsychologie und Ich-Analyse (Leipzig, 1921); Siltala, “Sodan psykohistoriaa,” pp. 53-54.

${ }^{\text {xxviii }}$ Cf. Joshua S. Goldstein, War and Gender: How Gender Shapes the War System and Vice Versa (Cambridge, 2004), p. 251.

xxix Hardly anything else frustrated the soldiers as much as problems in mail delivery; Sampo Ahto, Talvisodan henki: Mielialoja Suomessa talvella 1939-1940 (Porvoo, 1989), pp. 196197.

${ }^{\mathrm{xxx}}$ On correspondence in war, see Sonja Hagelstam, “Käraste soldat! Om krigstida brev som källmaterial,” Budkavlen (2000), pp. 66-84; Pipping, Kompaniet som samhälle, p. 150. xxxi Pipping, Kompaniet som samhälle, pp. 148-152; Ville Kivimäki, “Ryvetetty enkeli: Suomalaissotilaiden neuvostoliittolaisiin naissotilaisiin kohdistama seksuaalinen väkivalta ja sodan sukupuolittunut mielenmaisema,” Naistutkimus - Kvinnoforskning 19 (2007): 3, pp. 19-33.

xxxii Ateenalaisten laulu, a popular patriotic hymn of young warriors sacrificing themselves for the fatherland; original lyrics in Swedish by Viktor Rydberg, composed by Jean Sibelius in 1899. 
xxxiii SKS KRA, Korsu 1973, vol. VI, O.N., p. 18.

${ }^{\text {xxxiv }}$ Cf. Klaus Theweleit, Männerphantasien 1: Frauen, Fluten, Körper, Geschichte

(Frankfurt am Main, 1977), pp. 121-176; Goldstein, War and Gender, pp. 306-316;

Kivimäki, “Ryvetetty enkeli,” pp. 22-24.

xxxv SKS KRA, Korsu 1973, vol. III, Y.K., p. 16.

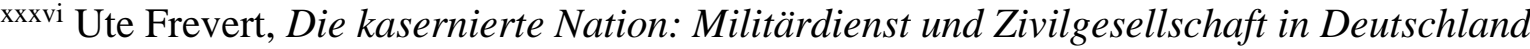
(München, 2001), pp. 228-232.

xxxvii Tuomas Tepora, "Poikien sota. Toisen maailmansodan aikaiset poikien sotakirjat siirtymän kuvauksena,” Historiallinen Aikakauskirja 105 (2007): 3, 287-301.

xxxviii Ilona Kemppainen, Isänmaan uhrit: Sankarikuolema Suomessa toisen maailmansodan aikana, Bibliotheca Historica no. 102 (Helsinki, 2006), pp. 234-243, 255.

xxxix SKS KRA, Korsu 1973, vol. VIII, E.P., p. 58.

${ }^{\mathrm{xl}}$ Kemppainen, Isänmaan uhrit, p. 68.

xli Goldstein, War and Gender, pp. 306-309.

xlii Member of the women's auxiliary corps in the Lotta Svärd organisation.

xliii SKS KRA, Satasärmäinen nainen Collection 1991, 11027-11131 (names changed), p. 11081.

xliv Jukka Kulomaa, Käpykaartiin? 1941-1944: Sotilaskarkuruus Suomen armeijassa jatkosodan aikana (Helsinki, 1995), pp. 136-147; cf. Mirkka Danielsbacka, ”Sotilaskurin rajoilla: Miehistön vastarinnan muodot ja merkitykset jatkosodan alkuvaiheessa,” Historiallinen Aikakauskirja 106 (2008): 3, 269-284.

xlv These are rather rough outlines, and, on the other hand, the average age of the field army was also lower in 1944; on age of deserters, see Kulomaa, Käpykaartiin?, pp. 128-129, 284285; cf. Tapio Nurminen, “Muuttuva armeija,” in Jukka Kulomaa \& Jarmo Nieminen, eds., Teloitettu totuus: Kesä 1944 (Helsinki, 2008), pp. 65, 71-72; the preliminary information on 
the average age of psychiatric casualties in 1941 and 1944 is based on Ville Kivimäki’s ongoing study of psychiatric military hospitals and their patients in war.

xlvi Kivimäki, “Ryvetetty enkeli,” pp. 25-28.

xlvii Marianne Junila, Kotirintaman aseveljeyttä: Suomalaisen siviiliväestön ja saksalaisen sotaväen rinnakkainelo Pohjois-Suomessa 1941-1944, Bibliotheca Historica no. 61 (Helsinki, 2000), pp. 146-165; Tiina Kinnunen, Kiitetyt ja parjatut: Lotat sotien jälkeen (Helsinki, 2006), pp. 138-139.

xlviii Cf. Susan Gubar, “'This Is My Rifle, This Is My Gun’: World War II and the Blitz on Women,” in Margaret R. Higonnet et al., eds., Behind the Lines: Gender and the Two World Wars (New Haven, 1987), pp. 240, 247, 250-252.

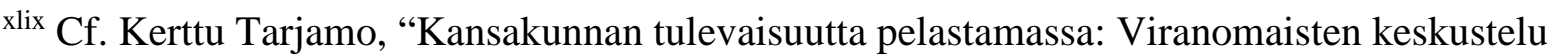
rikollisuudesta 1940- ja 1950-lukujen Suomessa,” in Petri Karonen \& Kerttu Tarjamo, eds., Kun sota on ohi: Sodista selviytymisen ongelmia ja niiden ratkaisumalleja 1900-luvulla, Historiallinen Arkisto no. 124 (Helsinki, 2006), pp. 348-349.

${ }^{1}$ Heikki Luostarinen, Perivihollinen: Suomen oikeistolehdistön Neuvostoliittoa koskeva viholliskuva sodassa 1941-44; tausta ja sisältö (Tampere, 1986), pp. 52, 388-403.

${ }^{\text {li }}$ Chris Hedges, War Is a Force That Gives Us Meaning (New York, 2002), pp. 37-38, 44-45, 59.

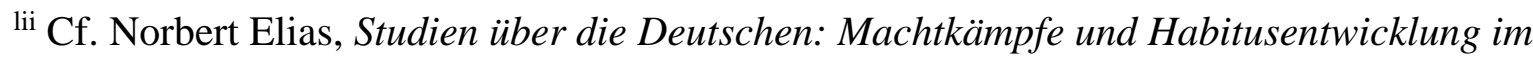
19. und 20. Jahrhundert, $2^{\text {nd }}$ ed. (Frankfurt am Main, 1994), pp. 196-204, 456-464.

liii Uusi Aura, 3 December 1939.

${ }^{\text {liv }}$ On the theoretical concepts of splitting and idealization in the object relations theories' tradition, see C. Fred Alford, Melanie Klein and Critical Social Theory: An Account of Politics, Art, and Reason Based on Her Psychoanalytic Theory (New Haven, 1989), pp. 29- 
37, 65-69, 73-74, 80-83; Charles Ashbach \& Victor L. Schermer, Object Relations, the Self, and the Group: A Conceptual Paradigm (London, 1994), pp. 69-71, 92-98.

${ }^{\mathrm{lv}}$ Cf. Janne Helin, Maa vahva, Jumala väkevä: Pyhä talvisota ja Kotimaa-lehden myytit 1939-1941, unpublished pro gradu thesis (University of Helsinki, 2006), pp. 72-86.

lvi Sari Näre \& Tuomas Tepora, “Suur-Suomen lapset Itä-Karjalassa,” in Sari Näre et al., eds., Sodassa koettua I: Haavoitettu lapsuus (Helsinki, 2007), p. 178.

lvii It has been argued that this tradition can be traced as far back as to German practices during the Napoleonic wars: Veli-Matti Syrjö, “Kultasormuksen tarina,” in Jari Leskinen \& Antti Juutilainen, eds., Talvisodan pikkujättiläinen (Helsinki, 1999), pp. 714-717; Petra Terhoeven, ““Nicht spenden, opfern’: Spendenkampagnen im nationalsozialistischen Deutschland und im faschistischen Italien als Disziplinierungs- und Integrationsinstrument,” in Armin Nolzen \& Sven Reichardt, eds., Faschismus in Italien und Deutschland: Studien zu Transfer und Vergleich (Göttingen, 2005).

${ }^{\text {lviii }}$ Cf. Hedges, War Is a Force, p. 37.

lix Vamik D. Volkan, The Need to Have Enemies and Allies: From Clinical Practice to International Relationships, (Northvale, N.J., 1988), pp. 99-110.

${ }^{\text {lx }}$ Finland declared independence on 6 December 1917, and the following Civil War from January to May 1918 resulted in the victory of the "White" government troops over the insurgent "Reds" of the socialist side. Civil War with its acts of terror and retribution poisoned the political atmosphere for much of the 1920s and 1930s.

lxi Tuomas Tepora, “Redirecting Violence: The Finnish Flag as a Sacrificial Symbol, 19171945," Studies in Ethnicity and Nationalism 7 (2007): 3; theoretically for the function of collective symbols in group formation, see Ashbach \& Schermer, Object Relations, pp. 218221.

lxii Suomen Sosialidemokraatti, 26 June 1940. 
lxiii We thank Jari Lindholm for information concerning the beliefs of the Finnish soldiers at the front.

lxiv SKS KRA, Korsu 1973, vol. VII, A.N., pp. 118-119.

lxv Catherine Merridale, Ivan's War: The Red Army 1939-45 (London, 2005), p. 168; for spiritualist beliefs of European soldiers in the World War I, see Winter, Sites of Memory, pp. 65-69.

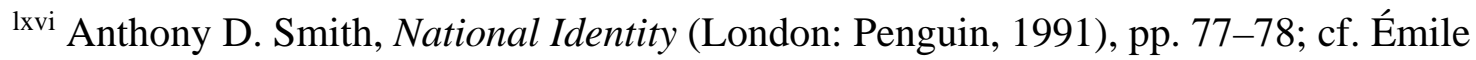
Durkheim, Formes élémentaires de la vie religieuse: Le système totémique en Australie (Paris, 1912).

lxvii Alford, Melanie Klein, pp. 57-103; Siltala, “Sodan psykohistoriaa,” pp. 55-58.

lxviii Kemppainen, Isänmaan uhrit, pp. 163-164, 225-226, 233-243.

${ }^{\text {lxix }}$ Cf. Carolyn Marvin \& David W. Ingle, Blood Sacrifice and the Nation: Totem Rituals and the American Flag (Cambridge, 1999); Anderson, Imagined Communities.

lxx Tepora, “Poikien sota,” p. 291.

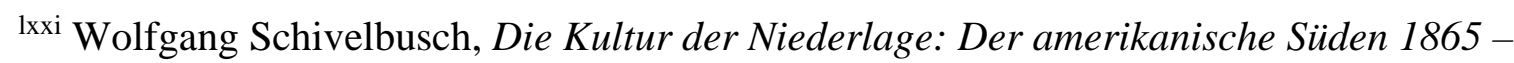
Frankreich 1871 - Deutschland 1918, 2 ${ }^{\text {nd }}$ ed. (Frankfurt am Main, 2003), pp. 319-327. lxxii John W. Dower, Embracing Defeat: Japan in the Wake of World War II (New York, 1999), pp. 148-167.

lxxiii Unto Ahokivi, Juurettomat (Porvoo, 1946), pp. 46-47.

lxxiv Marja Tuominen, “Me kaikki ollaan sotilaitten lapsia”: Sukupolvihegemonian kriisi 1960-luvun suomalaisessa kulttuurissa (Helsinki, 1991); cf. Dagmar Herzog, Sex after Fascism: Memory and Morality in Twentieth-Century Germany (Princeton, N.J., 2005). lxxv Ulla-Maija Peltonen, Muistin paikat: Vuoden 1918 sisällissodan muistamisesta ja unohtamisesta (Helsinki, 2003); Tepora, “Redirecting Violence.” 


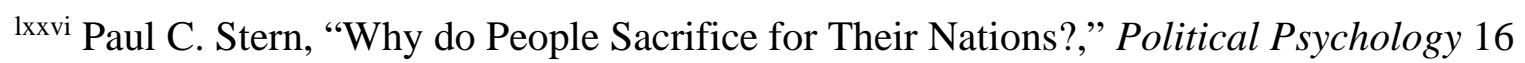
(1995): 2, pp. 217-235.

lxxvii Kemppainen, Isänmaan uhrit, pp. 113-142, 248.

lxxviii Winter, Sites of Memory, p. 22; see also Michael Sledge, Soldier Dead: How We

Recover, Identify, Bury, and Honor Our Military Fallen (New York, 2005), pp. 134-179.

lxxix George L. Mosse, Fallen Soldiers: Reshaping the Memory of the World Wars (Oxford, 1990), pp. 152-155.

lxxx Kemppainen, Isänmaan uhrit, pp. 73-78, 81-82, 249.

lxxxi Jenny Edkins, Trauma and the Memory of Politics (Cambridge, 2003), pp. 1-19; Chris R. Brewin, Posttraumatic Stress Disorder: Malady or Myth? (New Haven, 2003), pp. 18-20, 72, 83.

${ }^{\text {lxxxii }}$ Cf. Jay Winter, Remembering War: The Great War Between Memory and History in the Twentieth Century (New Haven, 2006), p. 214. 